\title{
Relationship Between Ischemic Modified Albumin (IMA) and Chronic Hepatitis B
}

\author{
iskemik Modifiye Albumin (IMA) ile Kronik Hepatit B Arasındaki lișski
}

\author{
Neslihan Çelik', Cemile Biçer², Ayșe Çarlıoğlư ${ }^{3}$ Onur Çelik ${ }^{4}$ Salim Neșelioğlu²

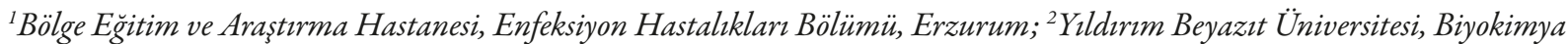 \\ Anabilim Dalı, Ankara; ${ }^{3}$ Bölge Eğitim ve Araşttrma Hastanesi, Endokrinoloji Bilim Dal, Erzurum; ${ }^{4}$ Bölge Eğitim ve Araştırma \\ Hastanesi, Göğüs Hastalıkları Bölümü, Erzurum, Türkiye
}

\begin{abstract}
Aim: Ischemic Modified Albumin (IMA) is a molecule that is found to be elevated in liver diseases with liver damage. In our study, the relationship between IMA and chronic hepatitis $B$ (CHB) was investigated.
\end{abstract}

Material and Method: Patients with $\mathrm{CHB}$ who were admitted to the Infectious Diseases polyclinic in between April 2016 and September 2016 and the healthy control group were included in the study. Fifty-three of the patients (24 female, 29 male) with $\mathrm{CHB}$ and 51 (21 female, 30 male) were the healthy control group. Blood samples were taken and centrifuged and serums were stored at $-80^{\circ} \mathrm{C}$. IMA levels were measured by spectrophotometric method. IMA/albumin ratio (IMAR) was calculated.

Results: IMA level was measured as $1.08 \pm 0.13$ in $\mathrm{CHB}$ patients and $0.96 \pm 0.11$ in control group $(r=0.42, p<0.000)$. And, also, IMAR level was measured as $0.23 \pm 0.03$ in $C H B$ and $0.20 \pm 0.03$ in control group $(r=0.43, p<0.000)$. According to the control group, the IMA and IMAR level elevation was statistically very significant in $\mathrm{CHB}$. However, there was no statistically significant difference between IMA and IMAR levels in CHB.

Conclusion: In our study, IMA and IMAR levels were found to be high in patients with $C H B$. This significant elevation should be investigated in terms of reflecting liver damage in large studies with other noninvasive parameters followed in patients with $\mathrm{CHB}$.

Key words: ischemic modified albumin; chronic hepatitis B; noninvasive parameter

\section{ÖZET}

Amaç: İskemik Modifiye Albumin (IMA) kronik karaciğer hastalıklarında, karaciğerdeki hasarla birlikte yükseldiği saptanan bir moleküldür. Bizim çalıșmamızda iMA'nın kronik hepatit B (KHB) ile ilișkisi irdelendi.

Materyal ve Metot: Nisan 2016 - Eylül 2016 tarihleri arasında Enfeksiyon Hastalıkları polikliniğine bașvuran KHB hastaları ve sağlıklı kontrol grubu çalıșmaya dâhil edildi. Hastaların 53'ü (24 kadın, 29 erkek) KHB ve 51'i (21 kadın, 30 erkek) sağlıklı kontrol grubunu olușturuyordu. Kanları alınıp santrifüj edildi ve serumlar $-80^{\circ} \mathrm{C}$ derecede saklandı. Bu serumlardan daha sonra, spektrofotometrik yöntemle, iMA düzeyleri ölçüldü. iMA/albumin oranı (IMAR) hesaplandı.

Bulgular: IMA düzeyi KHB hastalarında 1,08 0,13 , kontrol gru-

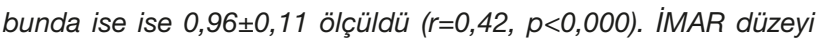

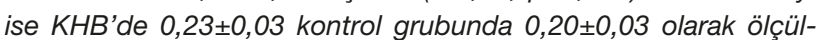
dü $(r=0,43, p<0,000)$. KHB'de kontrol grubuna göre IMA ve IMAR düzeyindeki yükseklik istatistiksel olarak çok anlamlıydı. Ancak KHB'de IMA ve IMAR düzeyleri arasında istatiksel olarak anlamlı fark saptanmadı.

Sonuç: Çalıșmamızda serum IMA ve IMAR düzeyleri KHB'li hastalarda yüksek olarak tespit edildi. Bu anlamlı yükseklik KHB'li hastalarda takip edilen diğer noninvazif parametreler ile birlikte yapılacak geniș çalıșmalarda karaciğer hasarını yansıtması açısından irdelenmelidir.

Anahtar kelimeler: iskemik modifiye albumin; kronik hepatit B; noninvaziv parametre

İetișim/Contact: Neslihan Celik, Bölge Eğitim ve Arasttırma Hastanesi, Enfeksiyon Hastalıkları Bölümü, Erzurum, Türkiye • Tel: 05336449208 • E-mail:drneslihancelik@yahoo.com.tr • Geliș/Received:27.10.2019 • Kabul/Accepted: 10.06.2020

ORCID: Neslihan Celik, 0000-0003-4543-9247 • Cemile Biçer, 0000-0001-7937-4475 • Ayşe Çarlıoğlu, 0000-0002-5622-9563 • Onur Celik, 0000-0002-9000-4851 • Salim Neşelioğlu, 0000-0002-0974-5717 


\section{Introduction}

Hepatitis B virus (HBV) infection is clinically observed as; acute infection, chronic infection or primary hepatocellular carcinoma (PHC). Chronic hepatitis is observed in $5-10 \%$ of patients; cirrhosis and liver failure may develop in $10 \%$ of chronic hepatitis patients ${ }^{1}$. Chronic and progressive liver diseases result in extensive damage to the liver parenchyma, which is replaced by collagenous scar tissue. Useful biochemical tests and researches on this subject are still ongoing ${ }^{2,3}$. Albumin is a protein, synthesized by liver ${ }^{4}$. It constitutes $60 \%$ of plasma proteins $s^{5}$. The main functions of albumin are adjusting osmotic pressure and transporting some metabolites in the blood. In many studies, it has been shown that metals such as cobalt, copper, and nickel can bound directly to albumin by amino terminal end ${ }^{6}$. Metal ion-binding properties of albumin are reduced in cases of ischemia, hypoxia, increased free radicals and acidosis.

This newly formed albumin is called Ischemic Modified Albumin (IMA) ${ }^{7}$. The literature reported that increased serum IMA concentrations and IMAR in chronic liver diseases of various etiologies also in several diseases such as myocardial ischemia, acute stroke, muscle ischemia, and bowel ischemia ${ }^{8}$.

The aim of our study is to investigate the relationship between IMA and IMAR levels with hepatitis B in $\mathrm{CHB}$ patients and to suggest a new laboratory parameter for future studies.

\section{Material and Method}

This study was conducted between May 2016 and July 2016 at the Erzurum Regional Training and Research Hospital Infectious Diseases Clinic. The study population included a total of 104 participants; $53 \mathrm{CHB}$ ( 24 women and 29 men) patients, and 51 healthy volunteers (21 women and 30 men) with no history of chronic illness or regular drug use.

The study was conducted in accordance with the Declaration of Helsinki and was approved by the Erzurum Regional Training and Research Hospital Ethics Research Committee (2018/05-34).

All subjects had given a written informed consent prior to participation for the study. The patients who were clinically and serologically diagnosed and followed for at least 6 months as chronic hepatitis B were added to our study. Blood samples were taken as a routine control. Control group was selected from patients referred to our clinic with a diagnosis other than hepatitis B. Patients who were under systemic steroid treatment and diagnosed with cerebrovascular disease, chronic and acute kidney disease, additional liver disease, acute and chronic systemic disease like malignancy excluded from our study. Chronic usage of drugs such as antioxidant, antilipid, vitamin drugs, smokers and alcoholics were also excluded from the study.

After blood sample was taken, plasma and serum were separated by centrifuging at 1500 revolutions per minute (rpm) for ten seconds. Serum was kept in $-80^{\circ} \mathrm{C}$ in ependorf tubes. Afterwards IMA was studied from the same blood sample. Patients' complete blood count $(\mathrm{CBC})$, biochemical parameters and hepatitis markers, HBV-DNA levels were also recorded.

IMA values were measured using the cobalt binding test. According to this method, a protein called cobalt (Co) and dithiothreitol (DTT) was added to the serum to measure the binding capacity of albumin. The reaction of the cobalt was measured spectrophotometrically. This amount of free Co indicates the IMA level ${ }^{9}$. In our study, $50 \mathrm{uL}$ of $1 \mathrm{~g} / \mathrm{L}$ cobalt chloride solution was added in $200 \mathrm{uL}$ of serum and kept at room temperature for 10 minutes. Then $50 \mathrm{uL}$ of $1.5 \mathrm{~g} / \mathrm{L}$ DTT solution was added and mixed. The color change of the sample was evaluated at $470 \mathrm{~nm}$ and the values were measured and recorded in the absorbance units (AbsU). Using IMA/serum albumin concentration $(\mathrm{g} / \mathrm{dL})$ formula IMAR was calculated.

Total protein (TP), albumin, alanine aminotransferase (ALT), aspartate aminotransferase (AST), gamma glutamil transferase (GGT), alkaline phosphatase (ALP) was measured with the autoanalyzer. (Architect c16000, Abbott, USA). All CBC analysis was performed in the hematology laboratory of our hospital with the use of an autoanalyzer. (Cell-Dyn Ruby, Abbott, USA). Hepatitis B markers were performed by autoanalyzer. (Architect i2000 sr, HBV-DNA RT PCR Rotorgene (Giasymphny), Abbott, USA).

\section{Statistical Analyses}

With an alpha error of 0.05 and significance level of 0.05 ; and when the incidence of hepatitis B is regarded as $4 \%$ in our region, the study power was calculated as $\mathbf{9 8 \%}$. We performed all statistical analyses using Statistical Package for the Social Sciences (SPSS Inc. for Windows, version 17.0, USA). Continuous variables were expressed as means \pm Standard Derivation (SD). To test the normality of variable distributions, 


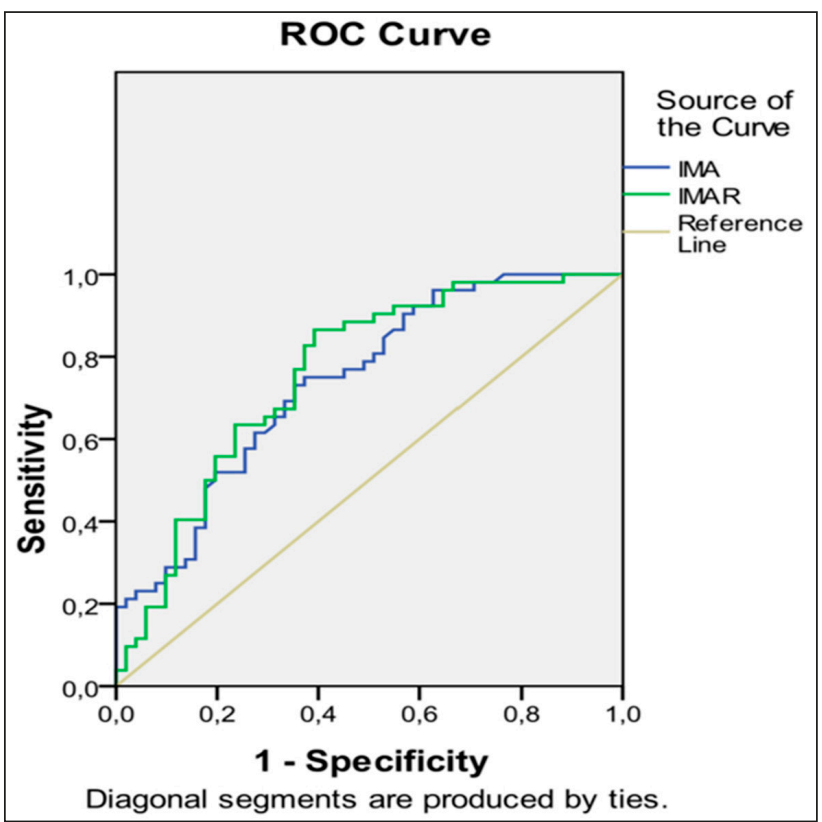

Figure 1. IMA (ischemic modified albumin) and IMAR (ischemic modified albumin to albumin ratio) level ROC (receiver operating characteristic) curve in chronic hepatitis B patients: $78 \%$ specificity and $59 \%$ sensitivity for IMA $>0.97$ predicts $C H B(A U C=74 \% ; p=0.000) ; 89 \%$ specificity and $59 \%$ sensitivity for IMA $>0.2$ predicts $C H B$ ( $A U C=75 \%$; $p=0.000)$ ( $A U C$, area under curve).

a one-sample Kolmogorov-Smirnov test was used. Unless otherwise stated, results were expressed as mean $\pm S D$. We used the Mann-Whitney $U$ test or independent sample $t$ test between two subject groups, and used the Pearson correlation test or Spearman correlation test, as appropriate. Categorical data were analyzed by Chi-square test. The receiver operating characteristic (ROC) curve analysis assessed the cutoff IMA/IMAR levels the best diagnostic accuracy for detecting differentiated CHB. $\mathrm{p}<0.05$ was considered statistically significant.

\section{Results}

In this cross-sectional study, 53 patients with $\mathrm{CHB}(24$ women and 29 men), and 51 control (21 women and 30 men) subjects were evaluated $(\mathrm{p}<0.55)$. Mean age \pm SD of subjects were $39.79 \pm 13.11$ in the hepatitis group and $34.54 \pm 13.39$ in the control group $(p=0.05)$. Age and sex matched between patient and control groups.

IMA level was calculated as $1.08 \pm 0.13$ in $\mathrm{CHB}$ patients and $0.96 \pm 0.11$ in control group $(\mathrm{r}=0.42, \mathrm{p}<0.000)$. Also, IMAR level was measured as $0.23 \pm 0.03$ in $\mathrm{CHB}$ and $0.20 \pm 0.03$ in control group $(\mathrm{r}=0.43, \mathrm{p}<0.000)$. According to the control group in $\mathrm{CHB}$, the elevation in IMA and IMAR level was statistically significant (Figure 1). However, there was no significant difference between IMA and IMAR levels in CHB.

In addition, there was a positive correlation between IMA level and age, ALP, and a negative correlation between Albumin, direct bilirubin (DB), ALT, GGT and alpha feto-protein (AFP) in CHB patients. There was a positive correlation between IMAR and age, Body mass index (BMI), ALP and a negative correlation between DB, ALT, GGT, AFP and Albumin.

There was no correlation between IMA and IMAR levels and HBV-DNA, Total protein, AST, thrombocytes in CHB. IMA and IMAR levels, demographic and laboratory values were compared between $\mathrm{CHB}$ and healthy control group (Table 1).

In addition, all parameters studied in patients with $\mathrm{CHB}$ were compared with IMA and IMAR levels (Table 2).

\section{Discussion}

In this study, $78 \%$ specificity and $59 \%$ sensitivity were found for IMA $>0.97$ in $\mathrm{CHB}$ (Area Under Curve $(\mathrm{AUC})=74 \%, \mathrm{p}=0.000) .89 \%$ specificity and $59 \%$ sensitivity for IMAR $>0.2$ were observed for the prediction of $\mathrm{CHB}(\mathrm{AUC}=\%$ 75, $\mathrm{p}=0.000)$. IMA and IMAR levels were significantly higher in $\mathrm{CHB}$ patients than healthy control group $\mathrm{p}<0.000$.

The numbers of studies that evaluate the association of serum IMA concentration and IMAR with disease progression in chronic liver diseases are limited. In these limited studies, there is a correlation between progression of the disease and elevation of IMA and IMAR $^{10-13}$.

$\mathrm{HBV}$ is one of the most common causes of chronic liver diseases in the World ${ }^{14}$. Synthesis and functions of albumin deteriorate in patients with liver failure ${ }^{15}$. Human serum albumin is the most abundant circulating protein in the plasma and shows important antioxidant activities ${ }^{16}$.

Studies have shown that new isoforms emerged as a result of changes in albumin structure due to different reasons ${ }^{15,17}$. IMA is the most important isoform of albumin ${ }^{8}$. Several studies have been performed on IMA, which has been shown to increase in cases such as ischemia, hypoxia, increased free radicals, and acidosis ${ }^{7}$. In another study, IMA levels were significantly higher in 4 groups of patients with brain infarction, 
Table 1. Demographics and laboratory findings of study population

\begin{tabular}{|c|c|c|c|}
\hline & Control n (51) & Chronic Hepatitis B (CHB) n (53) & $p$ value \\
\hline Sex (male) (n) & $51(30)$ & $53(29)$ & 0.55 \\
\hline Age (years) & $34.54 \pm 13.39$ & $39.79 \pm 13.11$ & 0.051 \\
\hline BMI $\left(\mathrm{kg} / \mathrm{m}^{2}\right)$ & $26.53 \pm 4.14$ & $27.08 \pm 3.51$ & 0.47 \\
\hline $\begin{array}{l}\text { Ischemic Modified Albumin } \\
\text { (IMA) }\end{array}$ & $0.96 \pm 0.11$ & $1.08 \pm 0.13$ & $0.000^{*}$ \\
\hline IMA/albumin ratio (IMAR) & $0.20 \pm 0.03$ & $0.23 \pm 0.03$ & $0.000^{*}$ \\
\hline WBC $\left(10^{3} / \mu \mathrm{L}\right)$ & $7880.4 \pm 1674.6$ & $7308.2 \pm 1931.6$ & 0.11 \\
\hline Platelet & $257.34 \pm 56$ & $277.06 \pm 86$ & 0.19 \\
\hline HBV-DNA & & $903275 \pm 4.1$ & $0.000^{*}$ \\
\hline ALT (U/L) & $20.90 \pm 10.19$ & $27.63 \pm 23.20$ & $0.000^{*}$ \\
\hline AST (U/L) & $21.37 \pm 9.27$ & $23.14 \pm 11.91$ & 0.287 \\
\hline GGT (U/L) & $26.05 \pm 40.15$ & $18.06 \pm 7.73$ & 0.094 \\
\hline Albumin $(\mathrm{g} / \mathrm{dL})$ & $4.84 \pm 0.39$ & $4.60 \pm 0.44$ & $0.004^{*}$ \\
\hline AFP & $4.42 \pm 0.43$ & $2.43 \pm 1.87$ & $0.000^{*}$ \\
\hline $\mathrm{TP}(\mathrm{g} / \mathrm{dL})$ & $7.03 \pm 0.42$ & $7.07 \pm 0.84$ & 0.129 \\
\hline ALP & $20.26 \pm 9.17$ & $89.46 \pm 38.17$ & $0.000^{*}$ \\
\hline IB & $0.24 \pm 0.20$ & $0.65 \pm 1.71$ & $0.000^{*}$ \\
\hline DB & $2.30 \pm 0.98$ & $0.21 \pm 0.11$ & $0.000^{*}$ \\
\hline
\end{tabular}

BMI, body mass index; WBC, white blood cell; ALT, alanine aminotransferase; AST, aspartate aminotransferase; GGT, gamma glutamil transferase; TP, total protein; ALP, alkaline phosphatase; AFP, alfa feto protein; $\mathrm{IB}$, indirect bilirubin; DB, direct bilirubin; HBV-DNA, hepatitis B virus deoxyribonucleic acid.

${ }^{*} \mathrm{p}<0.05$

Table 2. Bivariate correlation between IMA, IMAR parameters and other variables in CHB

\begin{tabular}{|c|c|c|c|c|}
\hline \multirow[b]{2}{*}{ Variables } & \multicolumn{2}{|c|}{ IMA } & \multicolumn{2}{|c|}{ IMAR } \\
\hline & $r$ & $p$ & $r$ & $p$ \\
\hline Group & 0.417 & 0.000 & 0.447 & 0.000 \\
\hline Age & 0.205 & 0.041 & 0.318 & 0.001 \\
\hline BMI & 0.062 & 0.537 & 0.219 & 0.029 \\
\hline HBV-DNA & 0.153 & 0.320 & 0.039 & 0.805 \\
\hline Albumin & -0.297 & 0.002 & -0.755 & 0.000 \\
\hline TP & -0.131 & 0.202 & -0.107 & 0.300 \\
\hline AFP & -0.479 & 0.000 & -0.503 & 0.000 \\
\hline GGT & -0.279 & 0.006 & -0.245 & 0.016 \\
\hline ALP & 0.328 & 0.001 & 0.370 & 0.000 \\
\hline ALT & -0.311 & 0.002 & -0.349 & 0.000 \\
\hline AST & 0.026 & 0.794 & 0.027 & 0.789 \\
\hline PLT & 0.013 & 0.905 & 0.100 & 0.348 \\
\hline BK & -0.043 & 0.669 & -0.031 & 0.761 \\
\hline I. Bilirubin & 0.034 & 0.744 & 0.033 & 0.751 \\
\hline D. Bilirubin & -0.440 & 0.000 & -0.452 & 0.000 \\
\hline
\end{tabular}

BMI, body mass index; WBC, white blood cell; ALT, alanine aminotransferase; AST, aspartate aminotransferase; PLT, Platelet; GGT, gamma glutamil transferase; TP, total protein; ALP, alkaline phosphatase; AFP, alfa feto protein; IB, indirect bilirubin; DB, direct bilirubin; HBV-DNA, hepatitis B virus deoxyribonucleic acid; IMA, ischemic modified albumin; IMAR, ischemic modified albumin to albumin ratio. $\mathrm{p}<0.05$ was accepted as statistically significant. 
epileptic seizure, transient ischemic attack (TIA) and intracerebral hemorrhage than control group ${ }^{18}$. Sinha et al. ${ }^{19}$ showed elevated IMA during the acute coronary episode without developing necrosis. In other studies, it has been shown that IMA increases in conditions such as cirrhosis, bacterial-viral infections, advanced cancers, stroke, pulmonary embolism and end-stage renal failure ${ }^{13,20}$. When the serum albumin concentration is lower, less cobalt bounds to albumin molecule and a more intense response occurs between cobalt ions and dithiothreitol (DTT). Consequently, lower albumin concentrations may cause proportionally higher IMA levels in the same patients. Because of the loss of albumin level, there is also loss of synthesis capacity in chronic liver patiens. In addition to IMA, IMAR is also measure which is believed to be more valuable. IMAR is a calculated with the ratio of IMA to serum albumin level ${ }^{11,12}$. In some studies, IMAR level has been shown to be useful as a liver function test $^{10}$. Therefore, IMA/albumin ratio (IMAR) was included in the study.

In our $\mathrm{CHB}$ patient group, there was a negative correlation between serum albumin levels and serum IMA and IMAR levels. To support this fact, in another study, negative correlation was observed between serum albumin and serum IMA and IMAR levels ${ }^{8}$.

In addition, there is negative correlation between $\mathrm{DB}$, ALT, GGT, AFP and IMA, IMAR levels, but found a positive correlation between ALP, age and IMAR, IMA. Also in Yavuz et al.'s ${ }^{8}$ study there was also positive correlation between IMA, IMAR and ALT, AST levels and negative correlation between IMA, IMAR and thrombocyte and white blood cell count. In our study, there was no correlation between HBV DNA, Total protein, AST, thrombocyte, white blood cell count and IMA, IMAR levels.

In this study, Yavuz et al. ${ }^{8}$ found that serum IMA and IMAR levels were increased as the degree of liver fibrosis in HBV-related chronic liver diseases. In patients with advanced fibrosis, IMAR serum level was found to be higher than IMA. In another study, Cakir et al. ${ }^{12}$ reported that serum IMA concentration and IMAR were higher in pediatric patients with chronic liver diseases with various etiologies than in healthy group. It was observed that IMA and IMAR levels were increased in children with the chronic liver disease; IMAR was positively correlated with endstage liver disease. Higher amount of IMAR levels were found especially in patients with advanced stage fibrosis compared to those with moderate fibrosis. In our study, level of fibrosis and IMA and IMAR levels could not be compared in patients as there were no biopsy results. There was no significant difference between IMA and IMAR levels in patients with CHB. This is due to the fact that our patients with $\mathrm{CHB}$ have laboratory and clinical findings that do not require biopsy and consisted of patients are not accepted as an advanced stage.

Chronic and progressive liver disease results in widespread damage in the liver parenchyma and replaces it with collagenous scar tissue. According to current clinical practice, liver biopsy is necessary for the diagnosis and treatment of progressive chronic liver disease. However, nowadays, the need for biochemical tests that can be easily repeated and is thought to show advanced stage liver fibrosis is increasing ${ }^{2,3}$. Since biopsy was not performed in our study, only non-cirrhotic chronic hepatitis B patients were included in the study and their fibrous levels were not determined. However, serum IMA and IMAR levels were significantly higher in $\mathrm{CHB}$ than healthy patients. In the present study of noninvasive diagnostic methods, this significant elevation should be examined in terms of reflecting liver damage in more comprehensive studies with other parameters in patients with $\mathrm{CHB}$.

\section{References}

1. Robinson WS. Hepatitis B virus and hepatitis D virus. In: Mandell GL, Bennett JE, Dlin R. editors. Mandell, Douglas and Bennett's Principles and Practice of Infectious Diseases, 5 th ed. Philedelphia Pennnsylvania: Churchill Livingstone; 2005. p.1652-85.

2. McGill DB, Rakela J, Zinsmeister AR, Ott BJ. A 21-year experience with major hemorrh ge after percutaneous liver biopsy. Gastroenterology 1990;99(5):1396-400.

3. Regev A, Berho M, Jeffers LJ, Milikowski C, Molina EG, Pyrsopoulos NT, et al. Sampling error and intra observer variation in liver biopsy in patients with chronic $\mathrm{HCV}$ infection. Am J Gastroenterol 2002;97(10):2614-8.

4. Bernardi M, Ricci CS, Zaccherini G. Role of human albumin in the management of complications of liver cirrhosis. J Clin Exp Hepatol 2014;4(4):302-11.

5. Sugio S, Kashima A, Mochizuki S, Noda M, Kobayashi K. Crystal structure of human serum albumin at $25 \mathrm{~A}$ resolution. Protein Eng 1999;12(6):439-46.

6. Roy D, Quiles J, Sharma R, Sinha M, Avanzas P, Gaze D, et al. Ischemia-modified albumin concentrations in patients with peripheral vascular disease and exercise-induced skeletal muscle ischemia. Clin Chem 2004;50(9):1656-60. 
7. Bar- Or D, Winkler JV, Vanbenthuysen K, Harris L, Lau E, Hetzel FW. Reduced albumin cobalt binding with transient myocardial ischemia after elective percutaneous trans luminal coronary angioplasty: a preliminary comparison to creatine kinase-MB, myoglobin, and troponin I. Am Heart J 2001;141(6):985-91.

8. Yavuz F, Biyik M, Asil M, Dertli R, Demir A, Polat H, et al. Serum ischemic modified albumin (IMA) concentration and IMA/albumin ratio in patients with hepatitis B-related chronic liver diseases. Turk J Med Sci 2017;47(3):947-53.

9. Piwowar A, Knapik - Kordecka M, Warwas M. Ischemia modified albumin level in type 2 diabetes mellitus - Preliminary report. Dis Markers 2008;24(6):311-7.

10. Jalan R, Schnurr K, Mookerjee RP, Sen S, Cheshire L, Hodges $S$, et al. Alterations in the functional capacity of albumin in patients with decompensated cirrhosis is associated within creased mortality. Hepatology 2009;50(2):555-64.

11. Chen CY, Tsai WL, Lin PJ, Shiesh SC. The value of serum ischemia modified albumin for assessing liver function in patients with chronic liver disease. Clin Chem Lab Med 2011;49(11):1817-21.

12. Cakir M, Karahan SC, Mentese A, Sag E, Cobanoglu U, Polat $\mathrm{TB}$, et al. Ischemia modified albumin levels in children with chronic liver disease. Gut Liver 2012;6(1):92-7.

13. Zuwala-Jagiello J, Warwas M, Pazgan-Simon M. Ischemiamodified albumin (IMA) is increased in patients with chronic hepatitis $\mathrm{C}$ infection and related to markers of oxidative stres and inflammation. Acta Biochim Pol 2012;59(4):661-7.
14. Lok AS, McMahon BJ. Practice Guidelines Committee, American Association for the Study of Liver Diseases. Hepatology 2001;34(6):1225-41.

15. Oettl K, Stadlbauer V, Petter F, Greilberger J, Putz-Bankuti C, Hallström $S$, et al. Oxidative damage of albumin in advanced liver disease. Biochim Biophys Acta 2008;1782(7-8):469-73.

16. Colombo G, Clerici M, Giustarini D, Rossi R, Milzani A, Dalle-Donne I. Redox albuminomics: oxidized albumin in human diseases. Antioxidants \& Redox Signaling 2012;17(11);1515-27.

17. Domenicali M, Baldassarre M, Giannone FA, Naldi M, Mastroroberto M, Biselli $M$, et al. Post transcriptional changes of serum albumin: clinical and prognostic significance in hospitalized patients with cirrhosis. Hepatology 2014;60:1851-60.

18. Abboud H, Labreuche J, Meseguer E, Lavallee PC, Simon O, Olivot JM, et al. Ischemia modified albumin in acute stroke. Cerebro Vasc Dis 2007;23:216-20.

19. Sinha MK, Roy D, Gaze DC, Collinson PO, Kaski JC. Role of "Ischemia modified albumin", a new biochemical marker of myocardial ischaemia in the early diagnosis of acute coronary syndromes. Emerg Med J 2004;21(1):29-34.

20. Carreiro-Lewandowski E. Update on cardiacbiomarkers. Lab Med 2006;37:598-605. 